\title{
Impact of insiders and outsiders of entrepreneurial firms on valuation in initial public offering
}

\author{
Zhijian $\mathrm{Xu}^{*}$ and Zhiyou Xie
}

\author{
* Correspondence: \\ xuzhijian@nju.edu.cn \\ School of Business, Nanjing \\ University, Hankou Road 22, Gulou \\ District, Nanjing 210093, China
}

\begin{abstract}
The studies of initial public offering pricing had been a popular interest of academic research recently, but there is still little study for entrepreneurial firms now. Under the asymmetric information hypothesis and signaling theory, we try to find some factors affecting the initial public offering pricing of entrepreneurial firms. Based on the 153 listed firms on China's Growth Enterprise Market, we do an empirical test for the correlation between initial public offering pricing and board of director independency, top management team ownership, venture capital existence, and reputation of underwriter. Finally, some research hypotheses are verified. As a result, we find that the top management team's ownership is significantly correlated to initial public offering pricing which means that the top management team plays a more important role in pricing of entrepreneurial firms as an insider, compared to board of director independency as an outsider's role. Also, we find that venture capital backing is significantly correlated to initial public offering pricing while underwriter reputation is not, which means that venture capital plays a more important role in pricing of entrepreneurial firms as an insider after it invested, compared to underwriter as an outsider.
\end{abstract}

Keywords: Entrepreneurial firm; Corporate governance; Initial public offering; Valuation; China; Growth Enterprise Market

\section{Background}

Valuation in initial public offerings (IPO) of firms has always received much academic attention. Scholars generally employ theories such as signaling theory under the asymmetric information to explain it. Grossman and Stiglitz (1980) suggest that the inadequate or unauthentic disclosure of information in an imperfect market and the different capabilities to acquire, perceive, and understand information of market participants will affect their decision making and the risk premium by holding different quantity and quality of information. Only information of price is offered in the stock market, and other information about a listed firm is highly asymmetric. Information asymmetry exists between regulatory authorities and listed companies, between listed companies and investors, as well as between institutional investors and individual investors. Greenwald and Stiglitz (1993) point out that information is the foundation of financial market operations, and hence, such information asymmetry would cause many problems for the market. For instance, due to prior information asymmetry, products with bad quality will drive out those with good quality because of adverse

(c) 2014 Xu and Xie; licensee Springer. This is an Open Access article distributed under the terms of the Creative Commons Attribution License (http://creativecommons.org/licenses/by/2.0), which permits unrestricted use, distribution, and reproduction in any medium, provided the original work is properly cited. 
selection, which will eventually result in the whole quality decline of the products traded in the market.

Allen and Faulhaber (1989) show that it is difficult for investors to effectively differentiate good from bad, when the performances of firms vary in the market. But the firms with good performances certainly wish to distinguish themselves from those with bad performances, and they generally can signal to the investors by making use of the IPO pricing. Although having a lower initial issue price, a firm can make up for its losses in IPO during the second public offerings with a higher issue price, a higher potential growth, and promising future prospects to investors. On the other hand, firms with bad performances are unwilling to do so because they do not have beautiful futures and the losses from low IPO prices may not be compensated by the next public offering of shares.

From the view of signal theory, investors can improve their weak position in information asymmetry by acquiring signals. Deeds et al. (1997) say that 'certain variables or indicators send signals to potential investors about the capabilities and thus future value of firms'. Some scholars (Daily et al. 2003) believe that insiders are more informed about the IPO firm's potential than outsiders. Specifically, the managers with high-quality information of firms will signal to potential investors through their capital structures or dividend policies (Ross 1977). With a lack of clear signals to evaluate the existing values or when such signals are unobservable, the organizational and governance symbol can be used as an effective way to reduce uncertainty in IPO.

Many researchers made a lot of empirical tests on signal in IPO valuation from different angles, but something is still in an equivocal way. Specially, there is still little study for entrepreneurial firms in China. As the characteristics, the insiders occupied a dominant position of the entrepreneurial firm's ownership in China, while there are nominated independent directors as decorations forced by regulation when the entrepreneurial firms go to IPO. Therefore, we tend to study the impact of insiders and outsiders on IPO valuation for entrepreneurial firms listed in China's Growth Enterprise Market and try to find something specially.

\section{Literature review and hypotheses}

In considering corporate governance, we generally focus on inside directors and outside directors, and board compositions are thought as the proportion of outside and inside directors on the board. Specially, the existence of an outside director is regarded as a signal of the director's independency. Some researches argue that outside directors are effective in resolving agency problems (Johnson et al. 1996) because outsiders have incentive to signal their managerial competence to employers and their expertise in monitoring management. However, empirical evidence on the relationship between outside directors and firm performance is in an equivocal way. Schellenger et al. (1989) find that bigger percentages of outside directors are associated with increased financial performance, while others suggest that outside directors are ineffective in monitoring management. Arthurs et al. (2008) believe that internal supervision and experiences from the board of directors reduce IPO underpricing due to a higher valuation in IPO.

Baysinger and Butler (1985) show, based on a sample of 266 firms between 1970 and 1980 , that the firms with a higher proportion of independent directors have a better performance. Chahine and Filatotchev (2008) suggest that, according to agency theory, 
independent directors increase monitoring of the firm management and add to firm value with strategic advices and external knowledge and resources. With high costs of takeover, non-managing shareholders prefer strict monitoring of the management team by independent directors. The existence of independent directors also represents sound governance structure and offers outside investors with additional information that ensures better IPO performances. A more important finding of Leone et al. (2007) is that if the incumbent independent directors restrict the opportunism of the management and reduce the potential strategic mistakes, they also are able to limit unnecessary information disclosure, because excessive and unnecessary information disclosure will reduce competitiveness of the firm. Therefore, independent directors will raise IPO valuation. We offer the following hypothesis:

Hypothesis 1: The IPO valuation of entrepreneurial firms by means of the issue premium in IPO will be positively associated with the board independency measured by the percentage of independent director number; the higher the board independency measured by the percentage of independent director number is, the higher the valuation of an entrepreneurial firm by means of the issue premium in IPO is.

Kroll et al. (2007) suggest that the initial top management team (TMT) members have accompanied the firms for many years and possess tacit knowledge and common visions. The establishment of such common visions requires long time of fostering and continuous interaction. TMTs with common goals usually are more flexible, respond more quickly to changes, and handle problems better. They also believes that the initial TMTs are the primal providers of key human resources for IPO firms, and such human resources exist in the tacit knowledge and personal investment of TMT members in the growth processes of firms. The acquisition of tacit knowledge is also relatively difficult because it is established on the mutually trusting interpersonal relationship, while common visions are formed gradually in long-term work. The ownership status of TMT is observable by outside investors because firms are obliged to disclose the ownership status and compensatory arrangements of their TMTs. Beatty and Zajac (1994) point out that ownership arrangement enables the management team to diversify the risk of firm failure. Investors may regard such risk diversification as signals of management devotion and corporate quality and performance.

Jain and Kini (1994) believe that the performances of IPO firms are often unsatisfactory due to the agency problem. This echoes the opinion of Jensen and Meckling (1976) that managers of IPO firms may misuse their new positions as agents because they reap enormous monetary and non-monetary benefits by selling the shares they hold and having no exit costs to face. Therefore, if the TMT holds a larger proportion of the firm's shares, the agency problem will be less severe. Researches also show that the higher the proportion of firm shares held by its TMT, the more capable to signal to outside investors positively (Barney et al. 1996; Filatotchev and Bishop 2002; Florin et al. 2003).

Florin and Simsek (2007) suggest that managerial personnel are more inclined to underpricing when they can reap more benefits from IPO than their original benefits. Zimmerman (2008) thinks that TMT heterogeneity provides a signal to potential investors about the quality of IPO which is associated with greater capital accumulations in the future. Other researches find that the higher the proportion of firm shares held by its TMT, the more possibility to affect the issue price of IPO positively (Carter and Auken 1990; Certo 2003). 
The top management team, as the insiders of a firm, holds more information on the real value of an IPO firm than the outside investors. According to signaling theory, the shareholding of TMT delivers a message about the firm value. If TMT members sell stocks they hold largely, it means that the firm is overvalued. Hence, we offer the following hypothesis:

Hypothesis 2: The IPO valuation of entrepreneurial firms by means of the issue premium in IPO will be positively associated with the TMT ownership; the higher the TMT ownership is, the higher the valuation of an entrepreneurial firm by means of the issue premium in IPO is.

Amit et al. (1990) point out theoretically that adverse selection exists when venture capitals search for investment opportunities in start-up firms. Those entrepreneurs with low capabilities are willing to share their risks with outside organizations, while entrepreneurs with high capabilities like to manage firms by themselves instead of allying partners. Some young and grandstanding venture capitalists attempt to accelerate IPO of firms which they invest in by using false signals of reputation and performance. Grandstanding effect suggests that young venture capital institutes are likely to push for premature IPO of firms in which they invest in order to reap reputation as soon as possible. Such inappropriate timing of IPO will inevitably result in higher underpricing in IPO.

Megginson and Weiss (1991) indicate that venture capital backing results in significantly lower initial returns and gross spreads, which support the certification role of venture capitalists in initial public offerings. Wong and Wong (2008) notice that although a number of studies show that the venture capitals (VCs) can ease underpricing issues and can help ventures generate better post-IPO operational performance in the US market, they find that the effects of $\mathrm{VC}$ participations in Hong Kong are different. They present that the underpricing issues of VC-backed IPOs are more severe than non-VC-backed IPOs, which means that firms with VC backing have higher underpricing in IPO, which means lower IPO valuation, than those without VC backing. In sum, considering the backgrounds of our research, we offer the following hypothesis:

Hypothesis 3: The IPO valuation of entrepreneurial firms by means of the issue premium in IPO will be negatively associated with the venture capital backing measured by venture capitals existing or not; the higher the venture capital backing measured by venture capitals existing or not is, the higher the valuation of an entrepreneurial firm by means of the issue premium in IPO is.

Underwriters play a very important role in IPO, like coordinating the allocation of interests among various stakeholders. Firms prefer to choose a stronger underwriter to show a positive signal to the outsiders in order to raise more money. However, the larger or stronger an underwriter is, the greater its bargaining power becomes. Because the main revenue of underwriters comes from their underwriting fees, management fees, sales allowances, and transaction commission of stock listing, given the fixed issuing costs, underwriters will attempt to convince the IPO firms to lower their issue prices so as to reduce risks; whether new stock issue may be successful is dependent on the market conditions.

Benveniste and Spindt (1989) suggest that underwriters have sufficient power to motivate institutional investors to disclose the authentic information they use to evaluate the values of the new IPO firms or reward them for behaving as good customers. Michaely and Shaw (1994) prove that the higher underwriter reputation will lower IPO 
underpricing. Rock (1986) and Pollock et al. (2004) believe that underpricing is the underwriters' reward for institutional investors to undertake the risks of adverse selection or behave as good customers.

From the view of institutional investors, the stable relationships with reputable underwriters are of higher values. It is reasonable to assume that underwriters with higher reputation will be more capable of rewarding their institutional investors and therefore able to offer their clients higher IPO premiums (Bradley and Jordan 2002).

Hypothesis 4: The IPO valuation of entrepreneurial firms by means of the issue premium in IPO will be negatively associated with the underwriter reputation measured by the market share of each underwriter; the higher the underwriter reputation measured by the market share of each underwriter is, the higher the valuation of an entrepreneurial firm by means of the issue premium in IPO is.

\section{Methods}

\section{Samples and data}

The sample to be studied comes from 153 firms listed on the Chinese Growth Firm Market, launched on October 30, 2009 to December 31, 2010, with stock code from 300001 to 300154; only the firm with stock code 300060 is removed because it failed to launch IPO successfully for some reasons. Data of the sample in this paper mainly come from the prospectus of IPO firms, Wind Database and Bloomberg Limited Partnership.

\section{Dependent variables}

$I P O$ valuation. It is regarded as the valuation in initial public offering of a firm, which is also known as the issue premium in IPO and equal to the relative difference between the offer price per share and net asset per share. The variables of IPO valuation can be calculated as follows:

$\mathrm{IPO}$ valuation $=($ Issue price per share - Net asset per share $) /$ Issue price per share

The data is extracted from and computed based on information in the Wind Database.

\section{Independent variable}

Board independency. Generally, most researches consider board members to be independent if they have neither financial nor family ties with the CEO and the firm (Hwang and Kim 2009). The board independency variable is measured as the percentage of the number of independent directors to the total number of directors on the board. Data is from the prospectus of the IPO firms.

TMT ownership. The TMT ownership variable is measured as the percentage of the equity owned by TMT to total equity of the firm. Data is from the prospectus of the IPO firms.

Venture capital backing. Venture capital backing has been argued and been shown to influence the ability of the firm to raise capital at IPO (Gulati and Higgins 2003). It is denoted as dummy variable: ' 1 ' for firms with $\mathrm{VC}$ backing and ' 0 ' for those without. Data is from the prospectus of the IPO firms.

Underwriter reputation. The reputation of the underwriter has been shown to be beneficial to IPO performance (Zimmerman 2008). The underwriter reputation is measured 
as the market share of each underwriter listed in the 2009 ranking of underwriters in Chinese capital markets released by Bloomberg Limited Partnership. The top 10\% underwriters will score 10 , and the score is reduced by 1 for every subsequent $10 \%$. Underwriters not listed in the ranking score 0 .

\section{Control variables}

There are some elementary factors influencing the IPO valuation of firms other than those discussed above. Therefore, some variables need to be studied as the control variables here. Such control variables include the following:

Firm age. Firm age, the time since founding, helped to control for organizations' maturity. Those that are older and larger suffer less from a 'liability of newness' (Singh et al. 1986). It is measured as the number of years from the setup of a firm to its IPO. Data is from the prospectus of the IPO firms.

TMT size. Team size is a frequently used control variable especially in management team-related research (Sanders and Carpenter 1998). It is measured as the number of TMT members. Data is from the prospectus of the IPO firms.

Founder control. The founder plays an important role in a new firm. The personal perceptions of the firm's founder influence the firm's strategy and operations (Baron et al. 1999). The founder-CEO's involvement in the growth and success of a firm since its inception may motivate the CEO to derive the benefits of an IPO (Fischer and Pollock 2004). Founder control is denoted as a dummy variable. If the founder of IPO firm owns more than $50 \%$ of its stocks, the firm is deemed as under the founder's control and marked as ' 1 '. Otherwise, the firm is marked as '0'. Data is from the prospectus of the IPO firms.

Board chairman control. The relationship between $\mathrm{CEO} /$ chair duality and firm performance has not shown consistent results (Daily and Dalton 1993). It is denoted as a dummy variable. If the board chairman of an IPO firm is also its general manager, the firm is deemed as under its board chairman's control and marked as ' 1 '. Otherwise, the firm is marked as ' 0 '. Data is from the prospectus of the IPO firms.

$P / E$ ratio at issuing. Price-earnings ratio at issuing is the ratio of the issue price per share of an IPO firm to its earnings per share last accounting period when it is issuing, which can measure the value to invest in the issue bidding. The variable is obtained from Wind Database.

IPO size. In studies of IPO, total size of issuance is often considered. A larger IPO is generally issued by long-established enterprises, which will reduce the perceived risk of issuance (Dunbar 2000). Beatty and Ritter (1986) called this phenomenon as 'empirical regularity'. Compared to the large established enterprises, the issuance of smaller firms generally faces the larger corresponding uncertainty. It is measured as the multiple of issue price and the number of issued shares in IPO. The data is obtained from Wind Database.

\section{Statistical analyses}

Firstly, the SPSS statistical analysis software is used to conduct descriptive statistical analyses on all independent variables and control variables and test for correlation among various influencing factors. Then, we examine the hypotheses by ordinary least squares hierarchical regression models and use IPO valuation as a dependent variable; board independency, TMT ownership, venture capital backing, and underwriter 
reputation as the independent variables; and firm age, TMT size, founder control, board chairman control, P/E ratio at issuing, and IPO size as the control variables.

The model is as follows:

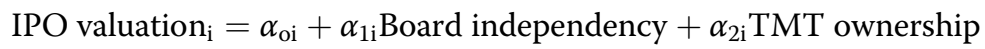

$+\alpha_{3 \mathrm{i}}$ Venture capital backing $+\alpha_{4 \mathrm{i}}$ Underwriter reputation $+\alpha_{5 \mathrm{i}}$ Firm age

$+\alpha_{6 \mathrm{i}}$ TMT size $+\alpha_{7 \mathrm{i}}$ Founder control $+\alpha_{8 \mathrm{i}}$ Board chairman control

$+\alpha_{9 \mathrm{i}} \mathrm{P} / \mathrm{E}$ ratio at issuing $+\alpha_{10 \mathrm{i}} \mathrm{IPO}$ size $+\varepsilon$

\section{Results}

\section{Descriptive statistical analysis}

Table 1 illustrates the results of descriptive statistical analysis of the dependent variable, independent variables, and control variables.

In the control variables, with regard to the firm age, the ages of the IPO firms on China's Growth Enterprise Market vary from a minimum of 4 years to a maximum of 24 years, and the average is approximately 10 years. It seems so much different with each other because China's Growth Enterprise Market was just launched and the China Securities Regulatory Commission remains cautious about the entrepreneurial firms listed on it. The TMT size varies from a minimum of 3 to a maximum of 9 , the mean close to 6 , with a relatively small standard deviation. The reason may be that the entrepreneurial firms need to establish a modern corporate governance system to gain market recognition before going public, so most of firms established a similar managerial structure of management teams. The average value for the variable 'founder control' is 0.86, indicating that most of entrepreneurial firms are controlled by their founders. This is consistent with the nature of entrepreneurial firms. The mean of the variable 'board chairman control' is 0.52 , indicating that there is approximately half of entrepreneurial firms wherein the board chairman and general manager are the same person. For the private and entrepreneurial firms, this may be attributed to the establishment of modern corporate governance.

Among the independent variables, with regard to the board independency, due to regulatory requirements, the proportion of independent directors must exceed one third in the board of directors, so the average number of the variable independent

Table 1 Descriptive statistics

\begin{tabular}{|c|c|c|c|c|c|}
\hline & Number & Minimum & Maximum & Mean & S.D. \\
\hline IPO valuation & 153 & 0.8 & 0.97 & 0.91 & 0.03 \\
\hline Firm age & 153 & 4 & 24 & 9.85 & 3.33 \\
\hline TMT size & 153 & 3 & 9 & 5.72 & 1.43 \\
\hline Founder control & 153 & 0 & 1 & 0.86 & 0.35 \\
\hline Board chairman control & 153 & 0 & 1 & 0.52 & 0.50 \\
\hline $\mathrm{P} / \mathrm{E}$ ratio at issuing & 153 & 36.98 & 138.46 & 68.60 & 19.70 \\
\hline IPO size & 153 & 9,000 & $2.70 \mathrm{E}+05$ & $75,633.00$ & $43,168.47$ \\
\hline Board independency & 153 & 0.33 & 0.67 & 0.36 & 0.05 \\
\hline TMT ownership & 153 & 0 & 0.96 & 0.42 & 0.27 \\
\hline VC backing & 153 & 0 & 1 & 0.64 & 0.48 \\
\hline Underwriter reputation & 153 & 0 & 10 & 6.92 & 3.14 \\
\hline
\end{tabular}


directors' in the sample is 0.36 and standard deviation is 0.05 , indicating no significant difference in the board independency of IPO firms on China's Growth Enterprise Market. The ratio of TMT ownership varies from a minimum of 0 to a maximum of 0.96 with a mean of 0.42 and standard deviation of 0.27 . This indicates significant differences in terms of this variable among IPO firms on the China's Growth Enterprise Market. The average of the variable 'venture capital backing' is 0.64 , meaning that $64 \%$ of the firms have VC backing. However, in-depth research reveals that many venture capitals in the entrepreneurial firms joined them just before their IPO. The mean of the variable 'underwriter reputation' is 6.92, which shows that underwriters with higher rankings will gain more recognition from issuers. The average of the variable 'first day turnover rate' is $75.18 \%$, showing extremely frequent and active trading of the stocks of the IPO firms on the first day of listing. The average of the variable 'allotment ratio of subscription' is $0.77 \%$ which is very low. It is clear that the supply and demand of the new stocks offered are highly unbalanced. The mean of the variable 'market heat' is $-3.219 \mathrm{E} 4$, and its standard deviation is $89,094.63$, indicating significant differences in the market heat of IPO firms in different industries. The compound profit variable varies from a minimum of -1.46 to a maximum of 6.15 with a mean of 0.0034 , indicating that the prior performance of different firms varies significantly.

\section{Hypothesis testing}

The correlation between IPO valuation and its four independent variables, as well as the control variables, is illustrated in Table 2. Mostly, correlations among various independent variables and control variables are insignificant or significant but with a small coefficient. Only the correlation coefficient between board chairman control and TMT ownership is significant with a relatively bigger coefficient of 0.59 , more than 0.5 . In accordance with the rules, it should have been considered that one of the variables is alternated by another variable. Considering that one is the independent variable and another one is the control variable and that they do not have interactive influence, we still retain both for further detailed study. However, it is reasonable because the board chairman of a firm normally owns a large proportion of shares. When the board chairman and the general manager of a firm are the same person, the proportion of shares held by the TMT will increase significantly as a result. Excluding it, there are no obvious correlations among the various independent variables and control variables, or the correlation coefficients are less than 0.5 .

IPO valuation is significantly correlated to firm age, P/E ratio at issuing, IPO size, TMT ownership, and venture capital backing.

As illustrated in Table 3, IPO valuation is used as a dependent variable, while firm age, TMT size, founder control, board chairman control, P/E ratio at issuing, and IPO size are used as control variables, and board independency, TMT ownership, VC backing, and underwriter reputation are used as independent variables to test hypotheses 1, 2, 3, and 4 .

In model 1, only control variables are inputted, and the result of analysis shows that firm age and IPO size, especially P/E ratio at issuing, are significantly correlated to IPO valuation. However, the significant correlation between IPO valuation and P/E ratio at issuing can be explained by the fact that the calculations of both variables involve the issue price.

In model 2, the board independency is inputted, and the result indicates that this variable has no significant correlation with IPO valuation, so hypothesis 1 is not verified. 
Table 2 Correlation matrix of IPO valuation with its independent variables and control variables

\begin{tabular}{|c|c|c|c|c|c|c|c|c|c|c|c|c|}
\hline & & 1 & 2 & 3 & 4 & 5 & 6 & 7 & 8 & 9 & 10 & 11 \\
\hline 1 & IPO valuation & 1 & & & & & & & & & & \\
\hline 2 & Firm age & $-0.225^{* *}$ & 1 & & & & & & & & & \\
\hline 3 & TMT size & -0.037 & 0.007 & 1 & & & & & & & & \\
\hline 4 & Founder control & 0.064 & 0.017 & 0.015 & 1 & & & & & & & \\
\hline 5 & $\begin{array}{l}\text { Board chairman } \\
\text { control }\end{array}$ & 0.078 & $0.161^{*}$ & $0.234^{* *}$ & $0.265^{* *}$ & 1 & & & & & & \\
\hline 6 & $\mathrm{P} / \mathrm{E}$ ratio at issuing & $0.572^{* *}$ & -0.149 & 0.081 & 0.063 & 0.127 & & & & & & \\
\hline 7 & IPO size & $0.237^{* *}$ & 0.043 & 0.088 & -0.053 & -0.024 & $0.229^{* *}$ & 1 & & & & \\
\hline 8 & $\begin{array}{l}\text { Board } \\
\text { independence }\end{array}$ & -0.03 & 0.08 & -0.08 & 0.129 & -0.111 & -0.093 & -0.033 & 1 & & & \\
\hline 9 & TMT ownership & $0.201^{*}$ & 0.037 & 0.11 & $0.341^{* *}$ & $0.590^{* *}$ & 0.082 & -0.031 & 0.066 & 1 & & \\
\hline 10 & VC backing & $-0.304^{* *}$ & -0.033 & 0.103 & 0.056 & $0.218^{* *}$ & -0.057 & -0.092 & -0.125 & 0.106 & 1 & \\
\hline 11 & $\begin{array}{l}\text { Underwriter } \\
\text { reputation }\end{array}$ & 0.071 & -0.121 & $0.178^{*}$ & -0.016 & 0.014 & $0.193^{*}$ & $0.184^{*}$ & 0.057 & -0.056 & $0.203^{*}$ & 1 \\
\hline
\end{tabular}

**Correlation is significant at the 0.01 level (two-tailed). * Correlation is significant at the 0.05 level (two-tailed).

In the descriptive statistical analysis, we find little difference of independent directors existing in IPO firms on China's Growth Enterprise Market. The board independency is also restricted to laws and regulations; therefore, the lack of explanatory function can be explained.

In model 3, the variable of TMT ownership is added. This variable is significantly correlated to IPO valuation; the regression coefficient is 0.223 with $p<0.05$. Hypothesis 2 is verified.

In model 4 , the variable of venture capital backing is added, and the regression coefficient is -0.278 with $p<0.001$. Hypothesis 3 is verified, and the explanatory function of the regression model is enhanced.

In model 5, the underwriter reputation variable is added, and there is no significant correlation with IPO valuation. Hypothesis 4 is not verified. Recall our reviews in the literature; many studies of the underwriter reputation's effect on IPO valuation

Table 3 Regression examination with IPO valuation as dependent variable

\begin{tabular}{|c|c|c|c|c|c|}
\hline Variables & Model 1 & Model 2 & Model 3 & Model 4 & Model 5 \\
\hline Firm age & $-0.160^{*}$ & $-0.163^{*}$ & $-0.148^{*}$ & $-0.173^{* *}$ & $-0.172^{* *}$ \\
\hline TMT size & -0.107 & -0.106 & -0.103 & -0.083 & -0.084 \\
\hline Founder control & 0.009 & 0.004 & -0.034 & -0.029 & -0.029 \\
\hline Board chairman control & 0.047 & 0.052 & -0.075 & -0.003 & -0.002 \\
\hline $\mathrm{P} / \mathrm{E}$ ratio at issuing & $0.520^{* * *}$ & $0.523^{* * *}$ & $0.524^{* * *}$ & $0.501^{* * *}$ & $0.500^{* * *}$ \\
\hline IPO size & $0.126^{+}$ & $0.126^{+}$ & $0.127^{+}$ & 0.103 & 0.102 \\
\hline Board independence & & 0.036 & 0.011 & -0.015 & -0.016 \\
\hline TMT ownership & & & $0.223^{* *}$ & $0.219^{* *}$ & $0.220^{* *}$ \\
\hline VC backing & & & & $-0.278^{* * *}$ & $-0.280^{* * *}$ \\
\hline Underwriter reputation & & & & & 0.007 \\
\hline F & 13.834 & 11.836 & 11.685 & 13.784 & 12.318 \\
\hline$R^{2}$ & 0.367 & 0.337 & 0.399 & 0.472 & 0.472 \\
\hline
\end{tabular}


by different scholars indicate positive correlation. Such a research result here is slightly beyond expectation.

\section{Conclusions}

Models 1, 2, 3, 4, and 5 examine the relationships between IPO valuation and board independency, TMT ownership, venture capital backing, and underwriter reputation. The results indicate that the regression coefficients between IPO valuation and board independency or underwriter reputation are insignificant, while the regression relationships between IPO valuation and TMT ownership, and venture capital backing are significant, where the signs of relationships are consistent with the hypotheses. This partly verifies the explanation by signaling theory under the hypothesis of asymmetric information for IPO valuation. However, we find it is special in China that the insiders occupied a dominant position of the entrepreneurial firm's ownership as Chinese characteristics, while there are nominated independent directors (outsiders) as decorations forced by regulation when the entrepreneurial firms go to IPO. If we regard the entrepreneurial firms from insider and outsider views, we find that the top management team plays a more important role in pricing of entrepreneurial firms as an insider, compared to board of director independency as an outsider's role, because the top management team's ownership is significantly correlated to initial public offering pricing while board of director independency is not. We also find that venture capital plays a more important role in pricing of entrepreneurial firms as an insider after it invested, compared to underwriter as an outsider, because venture capital backing is significantly correlated to initial public offering pricing while underwriter reputation is not. As mentioned earlier, the board independency, restricted by the special requirement in Chinese stock markets, is just a decoration. Also, the influence of underwriter reputation on IPO valuation still remains controversial.

\section{Discussions}

The results of this research show that the explanations of signaling theory under the hypothesis of asymmetric information to IPO valuation are partially verified. From the perspective of firms to be IPO, TMT's ownership of equity will signal to the investors about the good quality of a firm and the IPO firms should make use of such an influence mechanism. However, the venture capital, having an outstanding contribution in the development of entrepreneurial firms, negatively influences the issue price in IPO process. The firms, which hope to raise more money in IPO, should carefully weigh the pros and cons when choosing venture capitals.

\section{Limitation}

The first limitation is the newness of China's Growth Enterprise Market, only 153 firms in our sample of this paper. Specially, the firms which launched IPOs in 2009, due to the long preparation time of enormous market attention, have experienced high underpricing levels. This may result in biases in the results. Secondly, $R^{2}$ are still small in the above models which are less than 0.5 , so our models by only using asymmetric information theory are not sufficient to explain the reality of IPO valuation. A few theories still cannot fully explain such a complex economic phenomenon. 


\section{Future research}

This research is focused on the IPO valuation of entrepreneurial firms in China's Growth Enterprise Market. These firms have their special characteristics that say they may be different from IPO firms in the Growth Enterprise Market of other countries. So in the future, scholars may give attention to the international comparison between IPO in China's Growth Enterprise Market and the ones in the Growth Enterprise Market of other countries. On the other hand, due to market overheating on China's Growth Enterprise Market, investors give a high valuation to firms that IPO on the Market, which results in an excessive amount of money got by the IPO firms, and even far more than the firms needed. The IPO firms face the challenges in asset management. So, in the future, we can study the impact of over-raised funds on the growth and innovation of entrepreneurial firms, as well as the international difference.

\section{Competing interests}

The authors declare that they have no competing interests.

\section{Authors' contributions}

ZXu carried out the theoretical discussion, participated in the design of the study and drafted the manuscript. ZXie carried out the data collection and performed the statistical analysis. All authors read and approved the final manuscript.

\section{Acknowledgements}

The authors thank Yin Ye and Hailong Yu for their constructive comments on earlier versions of this paper. The authors are also grateful for the comments and suggestion from the anonymous reviewers.

Received: 8 June 2013 Accepted: 21 March 2014

Published: 15 May 2014

\section{References}

Allen F, Faulhaber GR (1989) Signalling by underpricing in the IPO market. Journal of Financial Economics 23:303-323 Amit R, Glosten L, Müller E (1990) Entrepreneurial ability, venture investments, and risk sharing. Management Science 36:1232-1245

Arthurs JD, Hoskisson RE, Busenitz LW, Johnson RA (2008) Managerial agents watching other agents: multiple agency conflicts regarding underpricing in IPO firms. Academy of Management Journal 51:277-294

Barney JB, Busenitz LW, Fiet JO, Moesel DD (1996) New venture teams' assessment of learning assistance from venture capital firms. Journal of Business Venturing 11:257-272

Baron J, Hannan M, Burton M (1999) Building the iron cage: determinants of managerial intensity in the early years of organizations. American Sociological Review 64:527-547

Baysinger BD, Butler HN (1985) Corporate governance and the board of directors: performance effects of changes in board composition. Journal of Law, Economics, \& Organization 1:101-124

Beatty RP, Ritter JR (1986) Investment banking, reputation, and the underpricing of initial public offerings. Journal of Financial Economics 15:213-232

Beatty RP, Zajac EJ (1994) Managerial incentives, monitoring, and risk bearing: a study of executive compensation, ownership, and board structure in initial public offerings. Administrative Science Quarterly 39:313-335

Benveniste L, Spindt P (1989) How investment bankers determine the offer price and allocation of new issues. Journal of Financial Economics 24:343-362

Bradley D, Jordan B (2002) Partial adjustment to public information and IPO underpricing. Journal of Financial and Quantitative Analysis 37:595-616

Brav A, Gompers PA (1997) Myth or reality? The long-run underperformance of initial public offerings: evidence from venture and non-venture capital-backed companies. Journal of Finance 52:1791-821

Carter RB, Auken VHE (1990) Personal equity investment and small business financial difficulties. Entrepreneurship Theory and Practice 15:51-60

Certo ST (2003) Influencing initial public offering investors with prestige: signaling with board structures. Academy of Management Review 28:432-447

Chahine S, Filatotchev I (2008) The effects of information disclosure and board independence on IPO discount. Journal of Small Business Management 46:219-241

Daily C, Dalton DR (1993) Board of directors leadership and structure: control and performance implications. Entrepreneurship Theory and Practice 17:65-81

Daily CM, Dalton DR, Cannella AA (2003) Corporate governance: decades of dialogue and data. Academy of Management Review 28(3):371-382

Dunbar CG (2000) Factors affecting investment bank initial public offering market share. Journal of Financial Economics 55:3-41

Filatotchev I, Bishop K (2002) Board composition, share ownership, and 'underpricing' of U.K. IPO firms. Strategic Management Journal 23:941-955

Fischer H, Pollock T (2004) Effects of social capital and power on surviving transformational change: the case of initia public offerings. Academy of Management Journal 47:463-481 
Florin J, Simsek Z (2007) The effects of moral hazard and adverse selection on the pricing and underpricing of initial public offerings. Venture Capital 9:127-143

Florin J, Lubatkin M, Schulze W (2003) A social capital model of high-growth ventures. Academy of Management Journal 46:374-384

Greenwald BC, Stiglitz JE (1993) Financial market imperfections and business cycles. Quarterly Journal of Economics 108:77-114

Grossman SJ, Stiglitz JE (1980) On the impossibility of informationally efficient markets. The American Economic Review 70:393-408

Gulati R, Higgins M (2003) Which ties matter when? The contingent effects of interorganizational partnerships on IPO success. Strategic Management Journal 24:127-144

Hwang BH, Kim S (2009) It pays to have friends. Journal of Financial Economics 93:138-158

Jain BA, Kini O (1994) The post-issue operating performance of IPO firms. Journal of Finance 49:1699-726

Jensen MC, Meckling WH (1976) Theory of the firm: managerial behavior, agency costs and ownership structure. Journal of Financial Economics 3:305-360

Johnson JL, Daily CM, Ellstrang AE (1996) Boards of directors: a review and research agenda. Journal of Management 22:409-438

Kroll M, Walters BA, Le SA (2007) The impact of board composition and top management team ownership structure on post-IPO performance in young entrepreneurial firms. Academy of Management Journal 50:1198-1216

Leone AJ, Rock S, Willenborg M (2007) Disclosure of intended use of proceeds and underpricing in initial public offerings. Journal of Accounting Research 45:111-153

Megginson WL, Weiss KA (1991) Venture capitalist certification in initial public offerings. The Journal of Finance 46:879-903

Michaely R, Shaw WH (1994) The pricing of initial public offerings: tests of adverse-selection and signaling theories. The Review of Financial Studies 7:279-319

Pollock TG, Porac JP, Wade JB (2004) Constructing deal networks: brokers as network 'architects' in the U.S. IPO market and other examples. Academy of Management Review 29:50-72

Rock K (1986) Why new issues are underpriced? Journal of Financial Economics 15:187-212

Ross SA (1977) The determination of financial structure: the incentive-signalling approach. The Bell Journal of Economics 8:23-40

Sanders W, Carpenter MA (1998) Internationalization and firm governance: the roles of CEO compensation, top team composition, and board structure. Academy of Management Journal 41:158-178

Schellenger MH, Wood DD, Tashakori A (1989) Board of director composition, shareholder wealth, and dividend policy. Journal of Management 15:457-467

Singh JV, Tucker DJ, House RJ (1986) Organizational legitimacy. Administrative Science Quarterly 31:171-193

Wong ALK, Wong MCS (2008) Examining the performance of venture-backed companies in the Hong Kong IPO market. The Journal of Private Equity 11:28-41

Zimmerman M (2008) The influence of top management team heterogeneity on the capital raised through an initial public offering. Entrepreneurship Theory and Practice 32:391-414

doi:10.1186/s40527-014-0004-6

Cite this article as: $\mathrm{Xu}$ and Xie: Impact of insiders and outsiders of entrepreneurial firms on valuation in initial public offering. Journal of Chinese Management 2014 1:4.

\section{Submit your manuscript to a SpringerOpen ${ }^{\circ}$} journal and benefit from:

- Convenient online submission

- Rigorous peer review

- Immediate publication on acceptance

- Open access: articles freely available online

- High visibility within the field

- Retaining the copyright to your article

Submit your next manuscript at $\boldsymbol{\sim}$ springeropen.com 